\title{
A comparison of the perceptual-auditory voice quality evaluation (GRBAS) and voice-related quality of life (K-VRQOL) according to choir type of elderly women choir members*
}

\author{
Hyeonjung Lee ${ }^{1} \cdot$ Binna Kang $^{1} \cdot$ Soo Ji Kim ${ }^{2, * *}$ \\ ${ }^{1}$ Department of Music Therapy, Graduate School, Ewha Womans University, Seoul, Korea \\ ${ }^{2}$ Music Therapy Major, Graduate School of Education, Ewha Womans University, Seoul, Korea
}

\begin{abstract}
The purpose of this study is to compare voice characteristics and voice-related quality of life (K-VRQOL) of the elderly female choir members using perceptual-auditory voice quality evaluation (GRBAS) and K-VRQOL scales. The participants were 77 women over 60 years old who were actively engaged in the choir in either Seoul or Busan. There are two kinds of choirs that indicate different engagement levels: regular choir and church choir. The perceptual-auditory vocal quality evaluation was listened to by / a / vowels and were graded by experts using the GRBAS scale. As a result, when comparing the differences between groups, the elderly female participants of the regular choir showed higher satisfaction in speech using the subjective speech recognition level than the elderly female members who performed in the church choir. In addition, the analysis showed that the satisfaction level was high in the physical function area of the K-VRQOL scale. This study confirmed that choral activities could yield positive results not only in terms of improving voice function in old age, but also to improve the subjective perception level of voice use, thus suggesting the necessity of systematic music programs to improve voices that are aging.
\end{abstract}

Keywords: elderly female choir, choir activity, voice-related quality of life (K-VRQOL) scale, perceptual-auditory vocal quaility evaluation, GRBAS scale

\section{1. 서론}

노인성 음성이란 노화로 인해 전반적인 신체기능이 저하되 면서 호흡 관련 기관 근육이 약화되어 나타나는 음성산출과 관 련된 기능적 변화를 뜻한다(Kendall, 2007). 인간의 목소리는 약
65세 이후에 정상적인 생리적 노화와 관련된 변화를 겪는다 (Tay et al., 2012). 노인성 음성은 일반적으로 목 쉰 소리, 바람 새 는 소리, 음성 떨림, 가늘고 약한 음성 등의 특징을 보인다(Kim, 2010; Gregory et al., 2012; Song, 2012). 노인음성의 특성은 성별 에 따라서도 차이를 보인다(Hong \& Kim, 2016). 특히 여성의 경

\footnotetext{
* This research is a revision of the first author's 2020 master's thesis.

** specare@ehwa.ac.kr, Corresponding author

Received 16 April 2020; Revised 28 May 2020; Accepted 28 May 2020

(C) Copyright 2020 Korean Society of Speech Sciences. This is an Open-Access article distributed under the terms of the Creative Commons Attribution NonCommercial License (http://creativecommons.org/licenses/by-nc/4.0) which permits unrestricted non-commercial use, distribution, and reproduction in any medium, provided the original work is properly cited.
} 
우 청년층과 노년층 음성의 기식성(breathless) 자체에는 큰 차이 가 없다는 최근 연구도 존재하지만(Lee et al., 2015), 20대, 50대 와 비교하여 70 대에 기본주파수가 급격히 낮아지면서 음성의 변화가 나타난다는 보고가 있다(Lee, 2006). 이는 폐경기 이후 내분비계의 변화로 인해 성대 비대 증상이 나타나고 성대조직 이 두꺼워지는 등 성대의 두께 및 질량의 증가로 인해 음고가 낮아지기 때문이다(Boone et al., 2010).

음성은 한 사람의 성별, 연령, 건강상태, 감정 등을 나타내며 음성에 문제가 생기면 삶의 질에 부정적인 영향을 미친다(Yoo, Kang \& Kim, 2018). 노화로 인한 노년기의 음성기능 약화는 의 사소통의 불편으로 연결되며(Verdonck-de Leeuw \& Mahiue, 2004; Yim et al., 2013), 인간이 대부분 목소리를 사용하여 의사 소통한다는 것을 고려하면 노년기 목소리 변화는 그들의 삶의 질(quality of life, QOL) 저하의 주요 요인이 된다(Etter et al., 2019). 음성은 의사소통 시 발화자의 감정을 반영하기 때문에 음성산출의 어려움은 사회적 기능을 제한할 수 있다(Song et al., 2000). 성공적인 노화의 개념에서 볼 때, 노년기 음성증상은 노 후생활에 주요한 영향을 주는 요인이다(Moon et al., 2019).

고령자의 음악활동 참여는 퇴직이나 사별, 거주지 이동 등의 경험으로 고립된 사회적 관계를 다시 이어주는 사회적 상호작 용의 수단으로 사용될 수 있다(Park \& Youn, 2019). 선행연구에 따르면 노인을 대상으로 한 노래 부르기 활동은 음성 개선 및 심리·정서적 측면에 긍정적인 영향을 미치는 것으로 보고되었 다(Han, 2017; Kim, 2018; Lee, 2014). 노인의 음악활용에 대한 연 구로는 심리·정서적 혜택을 강조하는 연구와 함께 노인의 음성 특성을 분석한 기초자료를 제시하는 연구 등이 보고되었다 (Hong \& Kim, 2016; Kim, 2019). 합창 활동을 하는 노인들의 개 인적 특성 및 참여 동기, 활동 참여 수준에 따른 노년기 심리·사 회적인 혜택에 대한 연구와(Choi, 2019; Yang, 2019), 노인을 위 한 지역 합창단 조직과 운영을 통해 노인들의 우울감과 외로움 을 줄이고 정신적 건강을 증진시킨 사례도 보고되었다(Johnson et al., 2018). 이처럼 합창활동에 참여하는 노인들의 심리사회적 혜택이나 음성관련 변화에 대한 연구가 각각 활발히 진행된 반 면, 합창참여 경험이나 수준과 연결하여 개인의 음성인식 및 변 화에 대한 관심은 부족한 편이다. 특히 노년기 합창활동 참여 유형이나 수준의 다양성을 고려해 볼 때 노인의 음성인식과 심 리사회적 지표의 차이를 알아보는 것이 필요한 시점이다.

본 연구에서는 노인의 성별, 연령, 주관적 건강상태와 같은 개인 특성과 합창단 참여 기간, 빈도, 공연 및 대회 참여 정도와 같은 합창활동 경험의 수준, 과거 합창 활동 경험과 주관적 음 석인식, 음성관련 삶의 질 수준의 차이를 알아보고자 한다. 또 한 이를 바탕으로 합창 경험 수준에 따른 음성특성 및 음성 관 련 삶의 질 수준 차이를 비교하여 살펴보고자 한다. 이를 위하 여 본 연구에서는 구속력(engagement) 수준에서 노년기 합창 유 형을 두 가지 형태로 구분하였다. 첫 번째는 ‘합창' 활동 자체에 지향성을 가지고 단원들의 구속력이 강화된 형태로써 입단 테 스트를 거쳐 일정 기간 동안 체계적인 연습 스케줄을 진행하며 공연, 경연 등을 주요 목표로 활동하는 형태이다. 두 번째는 교
회의 예배를 위한 도구적 지향성을 가지고 강한 구속력이나 일 괄적인 모집 과정 없이 개개인이 자연스럽게 입단하여 비교적 오랜 기간 동안 활동하는 형태이다. 이하 본 연구에서는 첫 번 째 형태를 합창단(Regular choir), 두 번째 형태를 찬양단(Church choir)이라 칭한다. 본 연구의 연구문제는 다음과 같다.

1) 합창활동에 참여하는 여성 노인의 합창 참여유형에 따른 개인적 특성 및 합창관련 변인은 어떠한가?

2) 합창활동에 참여하는 여성 노인의 합창 참여유형에 따른 주관적 건강상태 인식 및 주관적 음성 인식 수준, 음성관 련 삶의 질은 어떠한가?

3) 합창활동에 참여하는 여성 노인의 합창 참여유형에 따른 평가자의 청지각적 음성평가 점수는 어떠한가?

\section{2. 연구방법}

\section{1. 대상자}

본 연구는 2019년 11월 17일부터 11월 29일까지 서울 및 부산 소재의 실버 합창단 또는 시니어 합창단, 시니어 찬양단에서 활 동하는 노인들 중 연구 참여에 동의한 분들을 대상으로 하였으 며, 노인 77명(합창단: 29명, 찬양단: 48명)이 참여하였다. 합창 단과 찬양단의 단체 섭외는 서로 다른 경로를 통해 이루어졌다. 합창단의 섭외는 노인 합창대회 수상단체 목록에 첨부된 연락 처를 통해 연구 목적 및 내용을 설명하고 참여 여부 동의를 얻 어 조사를 진행하였다. 찬양단의 경우 오프라인 지휘자 모임 단 체를 통해 정기적인 연습모임을 하고 있는 경우 중 비전공자로 구성된 아마추어 단체를 섭외하였다. 참여자의 전공 여부는 지 휘자 및 합창단장을 통해 확인하였다. 연구 대상자는 만 60세 이상, 합창단 또는 찬양단에서 현재 활동 중이며, 비 흡연 중인 여성 노인 중 연구 윤리에 따라 연구의 목적과 방법, 연구 절차 등에 대해 자세한 구두 설명을 듣고 이해하였으며 자발적으로 연구에 참여하고자 의사를 밝힌 대상자이다. 이들은 실험 전 서 면 동의서를 작성한 후 본 연구에 참여하였다. 대상자 정보는 표 1 과 같다.

표 1. 대상자의 합창 참여유형에 따른 그룹별 개인 특성 Table 1. Demographic Information of Participants

\begin{tabular}{c|c|c|c|c}
\hline \multirow{2}{*}{ Category } & $\begin{array}{c}\text { Total } \\
(\mathrm{n}=77)\end{array}$ & $\begin{array}{c}\text { Regular choir } \\
(\mathrm{n}=29)\end{array}$ & $\begin{array}{c}\text { Church choir } \\
(\mathrm{n}=48)\end{array}$ \\
\cline { 2 - 5 } & $\mathrm{n}(\%)$ & $\mathrm{n}(\%)$ & $\mathrm{n}(\%)$ \\
\hline \multirow{4}{*}{ Age } & $60 \mathrm{~s}$ & $53(68.8)$ & $13(44.8)$ & $40(83.3)$ \\
\cline { 2 - 5 } & $70 \mathrm{~s}$ & $19(24.7)$ & $12(41.4)$ & $7(14.6)$ \\
\cline { 2 - 5 } & $80 \mathrm{~s}$ & $5(6.5)$ & $4(13.8)$ & $1(2.1)$ \\
\cline { 2 - 5 } & $M(S D)$ & $67.0(6.2)$ & $70.8(6.3)$ & $64.8(4.9)$ \\
\hline \multirow{2}{*}{ Region } & Seoul & $20(26.0)$ & $12(41.4)$ & $8(16.7)$ \\
\cline { 2 - 5 } & Busan & $57(74.0)$ & $17(58.6)$ & $40(83.3)$ \\
\hline
\end{tabular}




\section{2. 연구도구}

\subsection{1. 설문지 작성 및 자료 수집}

설문지는 대상자들의 인구사회학적 정보 및 합창단 참여 경 험, 주관적 건강상태 인식, 주관적 음성인식 만족도를 묻는 설 문지 1 과 한국판 음성관련 삶의 질 척도(voice-related quality of life, 이하 K-VRQOL) 설문지 2로 구성하였다. 설문지 1 의 문항 중 합창단 참여 경험은 현재 참여하고 있는 합창단의 구성 및 파트, 연습의 빈도 및 강도, 무대경험 정도와 합창단 참여 만족 도를 묻는 문항으로 구성되었다. 설문지 1 문항 중 주관적 음성 인식 만족도는 전반적 음성만족도, 음성문제 인식정도, 대화 시 음성만족도, 가창 시 음성만족도, 합창을 통한 음성 개선 정도 를 묻는 문항으로 구성되었다.

설문지 2는 K-VRQOL로 구성되어있으며, 사회·심리 영역과 신체기능 영역의 하위항목으로 이루어져 있다(Kim et al., 2007). 각 질문에 대한 답은 ‘문제가 전혀 없다'에 해당하는 1 점부터 ‘문제가 더 이상 나쁠 수 없을 만큼 심각하다’에 해당하는 5점까 지로 구성되어있다. 원 점수는 총 50 점이며, 이는 총점 100 점의 표준화 점수로 환산하여 점수가 높을수록 음성 사용에 어려움 이 없으며 삶의 질이 높은 것으로 볼 수 있다(Kim et al., 2007).

\subsection{2. 음성 평가}

청지각적 음성 평가 척도(perceptual-auditory voice quality evaluation, 이하 GRBAS)는 대상자의 음성을 듣고 검사자가 주 관적으로 평가하는 청지각 검사이다(Hirano, 1981). 이 평가방법 은 음향학적 검사도구인 Multidimensional Voice Program(MDVP), Praat, 공기역학적 검사도구인 Phonatory Aerodynamic System (PAS), 전기파형 검사도구인 Electroglottography(EGG) 등과 더 불어 음성평가를 위해 임상적으로 중요하게 여겨진다(Yoo et al., 2018). GRBAS 평가는 G(grade; 음성의 전반적인 쉰 소리), $\mathrm{R}$ (rough; 거친 소리), $\mathrm{B}$ (breathy; 바람 새는 소리), $\mathrm{A}$ (asthenic; 약 한 소리), $\mathrm{S}$ (strained; 쥐어짜는 소리)로 총 5 개의 하위항목으로 음성을 평가하도록 구성되어있다. 각 영역은 0 3점까지 4점 척 도로 평가하며, 0 점은 정상, 1 점은 경도, 2 점은 중도, 3 점은 심도 로 점수가 높을수록 음성증상의 심각도가 높은 것으로 평가한 다(Kim et al., 2007). 4점 척도의 특성상 1 점 단위의 평정 시 구분 이 명확하지 않을 경우 0.5 점까지 세분하여 표시할 수 있도록 허용하였다(Kim et al.,2007).

음성측정은 참여자의 편안한 말소리의 /a/ 모음 연장발성 3 초 간 3회 발성하도록 안내하여 실험을 진행하였다. 음성 평정은 재활병원에서 근무하는 두 명의 언어치료사가 평가하였다. 평 정은 녹음된 음성파일을 듣고 채점하는 방식으로 이루어졌으 며, 평가자의 근무경력은 각각 9 년, 15 년에 해당한다. 평정 의뢰 시 평가자에게 피험자의 음성파일 외에는 어떠한 정보도 제공 하지 않았다. 두 평가자 간의 신뢰도는 전체 음성평가 대상자 중 약 $20 \%$ 에 해당하는 15 명의 $\mathrm{G}$ 척도를 무작위로 추출하여 이 들의 관찰자 간 신뢰도를 산출하였으며, $90 \%$ 이상 $(93.3 \%)$ 의 일 치를 보였다.

\subsection{3. 음성자료 수집}

음성측정은 소음이 $40 \mathrm{~dB}$ 을 넘지 않는 공간에서 진행되었으 며, 대상자가 편안한 자세로 앉아 녹음을 할 수 있도록 안내 후 진행되었다. 마이크와 대상자의 입술간의 간격이 $15 \mathrm{~cm}$ 떨어진 위치에 마이크를 고정한 후 /a/ 모음 연장발성하는 음성파일을 녹음하였다. 분석을 위한 음성 녹음은 음성분석 프로그램 Praat 프로그램을 이용하여 컴퓨터에 업로드하였다. 음성 녹음을 위 해 Entertainment Dynamic Wired Microphone(Brits MC-1500B2K; Brits, Paju, Gyeonggi, Korea) 마이크를 사용하였으며, 마이크로 입력된 음성은 Focusrite Scarlett 2세대 USB 오디오 인터페이스 (Focusrite Scarlett Solo (2nd Gen) USB Audio Interface; Focusrite Plc, High Wycombe, Bucks)를 통해 컴퓨터에 녹음파일이 저장 될 수 있도록 하였다.

\section{3. 자료 분석}

앞서 밝힌 바와 같이 합창 참여유형에 따라 합창단과 찬양단 으로 그룹을 구분하고, 설문조사 및 음성평가를 통해 수집된 자 료가 그룹 간 차이를 보이는지 분석하였다. 수집된 자료는 SPSS 의 기술통계로 빈도와 백분율을 계산하였다. 합창 참여유형에 따라 합창활동에 참여하는 여성 노인의 개인적 특성 및 합창관련 변인, 주관적 건강상태 인식, 주관적 음성 인식 수준, K-VRQOL, GRBAS의 그룹 간 차이를 독립표본 $t$-검정(independent samples $t$-test)을 통해 분석하였다.

\section{3. 연구 결과}

3.1. 합창 참여유형에 따른 참여자의 개별 합창 경력 및 각 그룹의 특성

합창 경력과 관련된 영역에서는 활동 기간과 활동 파트로 구 분하였으며, 활동기간의 경우 전체 평균 $8.2(S D=10.1)$ 로 약 8 년 동안 활동한 것으로 응답되었다. 합창단원의 경우의 평균값은 $3.0(S D=2.6)$ 으로 평균 3 년간 활동한 것으로 나왔으며, 찬양단원 의 경우의 평균값은 $10.8(S D=10.7)$ 로 약 11 년간 활동한 것으로 응답하였다. 합창단원에 비해 찬양단원의 경우 평균적인 참여 기간이 길고, 통계적으로 유의미한 집단 간 차이 $(t=-3.827$, $p=.000)$ 를 보였다.

합창단 특성은 합창단의 연간 공연 참여 횟수, 합창단 구성 형태, 주당 연습 시간으로 나누어 분석하였다. 전체 참여자의 연간 무대공연 참여 횟수의 평균값은 $3.7(S D=4.7)$ 로 연간 약 4 회 공연에 참여하는 것으로 응답하였으며, 전체 범위는 0 회부터 12 회인 것으로 나타났다. 합창단원의 경우 평균 $1.4(S D=0.8)$, 찬 양단원의 경우 평균 $5.1(S D=5.5)$ 로 찬양단원의 무대경험 횟수가 많으며, 통계적으로 유의미한 집단 간 차이 $(t=-3.562, p=.001)$ 를 보였다.

주당 연습 시간은 전체 평균 $1.80(S D=0.3)$ 이며 약 2 시간의 연 습시간을 갖고 있으며, 그 범위는 1 시간부터 2 시간 30 분인 것으 로 조사되었다. 합창단원의 경우 평균 2.2 $(S D=0.3)$ 시간이며, 찬 양단원의 경우 평균 $1.8(S D=0.3)$ 시간으로 나타났다. 합창단원의 
경우 일주일에 최고 2시간 이상 정기적으로 합창 활동이 이루 어지고 있으며 최소 연습시간이 찬양단원보다 길고, 집단 간 통 계적으로 유의미한 차이( $(=6.777, p=.015)$ 를 보였다(표 2).

표 2. 합창 참여 유형에 따른 그룹별 참여자의 개별 합창 경력 및 각 그룹의 특성

Table 2. Individual choir career and choir characteristics according to the type of choir participation

\begin{tabular}{|c|c|c|c|c|c|}
\hline \multirow{2}{*}{\multicolumn{2}{|c|}{ Variable }} & $\begin{array}{l}\text { Total } \\
(n=77)\end{array}$ & $\begin{array}{c}\text { Regular } \\
\text { choir } \\
(n=29)\end{array}$ & $\begin{array}{l}\text { Church } \\
\text { choir } \\
(n=48)\end{array}$ & \multirow[t]{2}{*}{$t$-value } \\
\hline & & $M(S D)$ & $M(S D)$ & $M(S D)$ & \\
\hline $\begin{array}{c}\text { Individual } \\
\text { choir } \\
\text { career }\end{array}$ & $\begin{array}{l}\text { Activity } \\
\text { period } \\
\text { (year) }\end{array}$ & $8.2(10.1)$ & $3.0(2.6)$ & $10.8(10.7)$ & $-3.827^{* *}$ \\
\hline \multirow{2}{*}{$\begin{array}{c}\text { Choir } \\
\text { character- } \\
\text { istics }\end{array}$} & Performance & $3.7(4.7)$ & $1.4(0.8)$ & $5.1(5.5)$ & $-3.562^{* *}$ \\
\hline & \begin{tabular}{|c|} 
Weekly \\
practice time
\end{tabular} & $1.8(0.3)$ & $2.2(0.3)$ & $1.8(0.3)$ & $6.777^{*}$ \\
\hline
\end{tabular}

3.2. 합창 참여유형에 따른 그룹별 참여자의 주관적 건강상태 인식 및 음성 인식 수준, 합창참여 만족도

\subsection{1. 합창 참여유형에 따른 그룹별 참여자의 주관적 건강상태} 인식

연구대상자가 설문지에 자가 보고하는 형식으로 현재 본인 의 건강상태를 묻는 단일 문항을 통해 조사하였다. 전체 응답자 의 주관적 건강상태는 ‘보통이다' $44.2 \%$ (34명), ‘좋다' $37.7 \%(29$ 명), '매우 좋다' $10.4 \%(8$ 명), '나쁘다' $7.8 \%(6$ 명), '매우 나쁘다' $0 \%(0$ 명 $)$ 순으로 나타났다.

합창단원의 경우 주관적 건강상태는 ‘좋다' $44.8 \%(13$ 명), '보 통이다' $44.8 \%(13$ 명)가 가장 많은 비중을 차지하였으며, 다음으 로 '매우 좋다' $6.9 \%(2$ 명), '나쁘다' $3.4 \%(1$ 명)의 순으로 나타났 다. 찬양단원의 경우 주관적 건강상태는 '보통이다' $43.8 \%(21$ 명)가 가장 많은 비중으로 나타났으며, 다음으로 ‘좋다' $33.3 \%$ (16명), ‘매우 좋다' $12.5 \%$ (6명), ‘나쁘다' $10.4 \%(5$ 명)의 순으로 나 타났다. 주관적 건강상태의 전체평균이 $3.51(S D=0.79)$ 점이었으 며, 합창단원의 평균값이 $3.55(S D=0.69)$ 점, 찬양단원의 평균값 이 3.48( $(S D=0.85)$ 점으로 집단 간 차이가 통계적으로 유의미한 차이를 보이지 않았다.

3.2.2. 합창 참여유형에 따른 그룹별 참여자의 합창참여 만족도 합창참여 만족도를 합창 활동만족도와 사회적 활동만족도로 나누어 분석하였다. 합창활동 만족도의 경우 전체 평균은 8.95 $(S D=0.95)$ 점이며, 합창단원의 평균값이 $9.39(S D=0.53)$ 점, 찬 양단원의 평균값이 $8.82(S D=1.04)$ 점으로 나타났다. 합창단원의 경우 전체 평균보다 합창 활동의 만족도가 높았으며, 집단 간 통계적으로 유의미한 차이 $(t=2.779, p=.003)$ 를 보였다.

합창단원의 사회적 활동만족도의 경우 전체 평균은 8.86 $(S D=0.96)$ 점이며, 합창단원의 합창단 내 사회 활동 만족도의 평 균값은 9.25(SD=0.67)점, 찬양단원의 평균값은 $8.71(S D=1.04)$ 점
으로 나타났다. 사회 활동 만족도 역시 찬양단원의 경우보다 합 창단원의 경우에 점수가 높았으며, 집단 간 통계적으로 유의미 한 차이 $(t=2.501, p=.028)$ 를 보였다(표 3$)$.

표 3. 합창 참여 유형에 따른 참여자의 주관적 음성 인식 수준 Table 3. Subjective choir participant satisfaction according to the type of choir participation

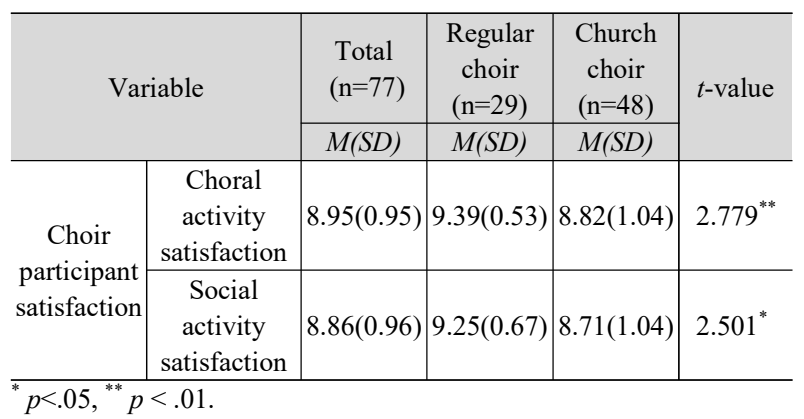

\subsection{3. 합창 참여유형에 따른 그룹별 참여자의 주관적 음성 인식} 수준

주관적 음성 인식 수준을 살펴보기 위해 5 가지의 문항을 통 해 조사하였다. 5 가지 문항은 전반적 음성 만족도, 음성 문제 인 식 정도, 대화 시 음성 만족도, 가창 시 음성 만족도, 합창을 통 한 음성개선 정도를 알아보기 위한 질문으로 구성되어있다. 각 문항은 4점 척도로 평가하며, 2번 문항만 역 코딩하였다.

전체 문항의 응답 결과를 합창 참여유형에 따라 살펴보았다. 주관적 음성 인식 수준과 음성 문제 인식 정도, 가창 시 음성 만 족도, 합창을 통한 음성개선 정도의 경우 합창단과 찬양단의 집 단 간 통계적으로 유의미한 차이를 보이지 않았다.

대화 시 음성 만족도를 평가하는 3 번 문항의 전체 평균값은 $2.69(S D=0.59)$ 점이었다. 합창단원의 평균값은 $2.86(S D=0.44)$ 점, 찬양단원의 평균값은 $2.58(S D=0.65)$ 점으로 나타나 합창단원이 찬양단원에 비해 대화 시 만족도 점수가 높았으며, 집단 간 차 이 $(t=2.048, p=0.001)$ 가 통계적으로 유의미 하였다(표 4).

표 4. 합창 참여 유형에 따른 참여자의 주관적 음성 인식 수준 Table 4. Subjective speech recognition level according to the type of choir participation

\begin{tabular}{|c|c|c|c|c|}
\hline \multirow[t]{2}{*}{ Item } & $\begin{array}{c}\text { Total } \\
(n=77)\end{array}$ & $\begin{array}{l}\text { Regular choir } \\
\quad(n=29)\end{array}$ & $\begin{array}{l}\text { Church choir } \\
\quad(n=48)\end{array}$ & \multirow[t]{2}{*}{$t$-value } \\
\hline & $M(S D)$ & $M(S D)$ & $M(S D)$ & \\
\hline 1 & $2.52(0.60)$ & $2.52(0.51)$ & $2.52(0.65)$ & -0.027 \\
\hline 2 & $2.00(0.70)$ & $2.07(0.70)$ & $1.96(0.71)$ & -0.665 \\
\hline 3 & $2.69(0.59)$ & $2.86(0.44)$ & $2.58(0.65)$ & $2.048^{*}$ \\
\hline 4 & $2.53(0.64)$ & $2.52(0.57)$ & $2.54(0.68)$ & -0.168 \\
\hline 5 & $2.99(0.60)$ & $3.03(0.57)$ & $2.96(0.62)$ & 0.553 \\
\hline Overall & $13.73(2.08)$ & $13.86(1.33)$ & $13.65(2.44)$ & $0.439^{*}$ \\
\hline
\end{tabular}

3.3. 합창 참여유형에 따른 그룹별 참여자의 $\mathrm{K}-\mathrm{VRQOL}$

본 연구에서 사용한 K-VRQOL의 하위항목은 사회·심리 영역 
및 신체 기능 영역으로 구성되었다. 총 10 문항을 각각 5 점 척도 로 응답하여 원 점수 50점을 표준화 점수 환산 공식으로 변환한 표준화 점수를 분석에 사용하였다. 각 문항의 원 점수는 ‘문제 가 전혀 없다’에 해당하는 1점부터 ‘문제가 더 이상 나쁠 수 없 을 만큼 심각하다'에 해당하는 5점까지 평가하는 방식으로 구 성되어 있다.

먼저 사회·심리 영역은 4번, 5 번, 8 번, 10 번 문항을 포함한다. 합창단원과 찬양단원의 평균값에서 집단 간 차이가 통계적으 로 유의미하지 않았다.

신체 기능 영역은 1 번, 2 번, 3 번, 6 번, 7 번, 9 번 문항을 포함한 다. 모든 문항에서 찬양단원의 평균값이 합창단원의 평균값보 다 높게 나타났다. 7 번 문항의 전체 평균값은 1.23 점 $(S D=0.61)$ 이며, 합창단원의 평균값은 $1.07(S D=0.26)$ 점, 찬양단원의 평균 값은 $1.33(S D=0.72)$ 점으로 찬양단원의 평균값이 높게 나타났다. 두 집단 간의 평균값은 통계적으로 유의미한 차이 $(t=-2.299$, $p=.025)$ 를 보이는 것으로 나타났다. 또한 9번 문항의 전체 평균값 은 $1.21(S D=0.55)$ 점이었다. 합창단원의 평균값은 $1.07(S D=0.19)$ 점, 찬양단원의 평균값은 $1.19(S D=0.53)$ 점으로 찬양단원의 평균값 이 합창단원의 평균값보다 높게 나타났다. 두 집단 간의 평균값 은 통계적으로 유의미한 차이 $(t=-2.112, p=.038)$ 를 보였다(표 5).

표 5. 합창 참여 유형에 따른 참여자의 음성관련 삶의 질(K-VRQOL) Table 5. K-VRQOL scales according to the type of choir participation

\begin{tabular}{|c|c|c|c|c|c|}
\hline \multirow{2}{*}{$\begin{array}{l}\text { Ques- } \\
\text { tion }\end{array}$} & \multirow{2}{*}{$\begin{array}{l}\text { Cate- } \\
\text { gory }\end{array}$} & $\begin{array}{c}\text { Total } \\
(\mathrm{N}=77)\end{array}$ & $\begin{array}{c}\text { Regular choir } \\
(\mathrm{n}=29)\end{array}$ & $\begin{array}{c}\text { Church choir } \\
(\mathrm{n}=48)\end{array}$ & \multirow[t]{2}{*}{$t$-value } \\
\hline & & $M(S D)$ & $M(S D)$ & $M(S D)$ & \\
\hline 1 & $\mathrm{PF}$ & $1.13(0.44)$ & $1.24(0.64)$ & $1.31(0.59)$ & -0.489 \\
\hline 2 & $\mathrm{PF}$ & $1.27(0.68)$ & $1.14(0.58)$ & $1.35(0.73)$ & -1.357 \\
\hline 3 & $\mathrm{PF}$ & $1.23(0.58)$ & $1.17(0.60)$ & $1.27(0.57)$ & -0.708 \\
\hline 4 & SE & $1.28(0.67)$ & $1.24(0.64)$ & $1.46(0.68)$ & -1.386 \\
\hline 5 & SE & $1.43(0.80)$ & $1.48(0.87)$ & $1.40(0.77)$ & 0.444 \\
\hline 6 & $\mathrm{PF}$ & $1.05(0.28)$ & $1.00(0.0)$ & $1.08(0.35)$ & -1.289 \\
\hline 7 & $\mathrm{PF}$ & $1.23(0.61)$ & $1.07(0.26)$ & $1.33(0.72)$ & $-2.299^{*}$ \\
\hline 8 & SE & $1.14(0.48)$ & $1.07(0.26)$ & $1.19(0.57)$ & -1.053 \\
\hline 9 & $\mathrm{PF}$ & $1.21(0.55)$ & $1.07(0.26)$ & $1.29(0.65)$ & $-2.112^{*}$ \\
\hline 10 & SE & $1.13(0.44)$ & $1.03(0.19)$ & $1.19(0.53)$ & -1.817 \\
\hline \multicolumn{2}{|c|}{$\begin{array}{l}\text { Standardized } \\
\text { score of SE }\end{array}$} & $93.26(11.77)$ & $94.83(9.75)$ & $92.32(12.84)$ & 0.906 \\
\hline \multicolumn{2}{|c|}{$\begin{array}{c}\text { Standardized } \\
\text { score of PF }\end{array}$} & $94.64(10.05)$ & $97.13(5.47)$ & $93.14(11.80)$ & $2.009^{*}$ \\
\hline \multicolumn{2}{|c|}{$\begin{array}{l}\text { Overall stand- } \\
\text { ardized score }\end{array}$} & $94.38(10.77)$ & $96.98(8.25)$ & $92.81(11.85)$ & 1.666 \\
\hline \multicolumn{6}{|c|}{${ }^{*} p<.05$} \\
\hline \multicolumn{6}{|c|}{$\begin{array}{l}\text { K-VRQOL, voice-related quality of life; PF, Physical function; SE, } \\
\text { Social·emotional. }\end{array}$} \\
\hline
\end{tabular}

\section{4. 합창 참여유형에 따른 언어치료사의 GRBAS 평정}

언어치료사의 GRBAS 평정 점수를 합창활동 유형에 따라 그 룹별로 분석하였다. 먼저, 전반적인 쉰 목소리를 평가하는 $\mathrm{G}$ 점 수는 전체 응답의 평균값이 $0.26(S D=0.28)$ 점이었다. 합창단원의 평균값은 $0.28(S D=0.36)$ 점, 찬양단원의 평균값은 $0.25(S D=0.39)$ 점으로 합창단원의 평균값이 찬양단원의의 평균값보다 높게 나타났으나 집단 간 차이 $(t=0.394, p=0.695)$ 가 통계적으로 유의
미하지 않았다. 거친 소리를 평가하는 R 점수는 전체 응답의 평균 값이 $0.09(S D=0.24)$ 점이었다. 합창단원의 평균값은 $0.10(S D=0.25)$ 점, 찬양단원의 평균값은 $0.08(S D=0.24)$ 점으로 합창단원의 평균 값이 찬양단원의 평균값보다 높게 나타났으나 집단 간 차이 $(t=0.352, p=0.726)$ 가 통계적으로 유의미하지 않았다. 바람 새는 소리를 평가하는 $\mathrm{B}$ 점수는 전체 응답의 평균이 $0.13(S D=0.26)$ 점 이었다. 합창단원의 평균값은 $0.18(S D=0.29)$ 점, 찬양단원의 평 균값은 $0.09(S D=0.25)$ 점으로 합창단원의 평균값이 찬양단원의 평균값보다 높게 나타났으나 집단 간 차이 $(t=1.411, p=0.162)$ 가 통계적으로 유의미하지 않았다. 약한 소리를 평가하는 $\mathrm{A}$ 점수 는 전체 응답의 평균값이 $0.02(S D=0.10)$ 점이었다. 합창단원의 평균값은 $0(S D=0)$ 점, 찬양단원의 평균값은 $0.03(S D=0.12)$ 점으 로 찬양단원의 평균값이 합창단원의 평균값보다 높게 나타났 으나 집단 간 차이 $(t=-1.770, p=0.083)$ 가 통계적으로 유의미하지 않았다. 쥐어짜는 소리를 평가하는 $\mathrm{S}$ 점수는 전체 응답의 평균값 이 $0.01(S D=0.07)$ 점이었다. 합창단원의 평균값은 $0.02(S D=0.06)$ 점, 찬양단원의 평균값은 $0.01(S D=0.07)$ 점으로 합창단원의 평균 값이 찬양단원의 평균값보다 높게 나타났으나 집단 간 차이 $(t=0.418, p=0.677)$ 가 통계적으로 유의미하지 않았다(표 6).

표 6. 합창 참여 유형에 따른 그룹 별 청지각적 음성평가 점수 Table 6. Perceptual-auditory vocal quality evaluation according to the type of choir participation

\begin{tabular}{|c|c|c|c|c|}
\hline \multirow[t]{2}{*}{ Category } & $\begin{array}{c}\text { Total } \\
(\mathrm{N}=77)\end{array}$ & $\begin{array}{l}\text { Regular choir } \\
\quad(n=29)\end{array}$ & $\begin{array}{l}\text { Church choir } \\
\quad(n=48)\end{array}$ & \multirow[t]{2}{*}{$t$-value } \\
\hline & $M(S D)$ & $M(S D)$ & $M(S D)$ & \\
\hline Grade & $0.26(0.38)$ & $0.28(0.36)$ & $0.25(0.39)$ & 0.394 \\
\hline Rough & $0.09(0.24)$ & $0.10(0.25)$ & $0.08(0.24)$ & 0.352 \\
\hline Breathy & $0.13(0.26)$ & $0.18(0.29)$ & $0.09(0.25)$ & 1.411 \\
\hline Asthenic & $0.02(0.10)$ & $0(0)$ & $0.03(0.12)$ & -1.770 \\
\hline Strained & $0.01(0.07)$ & $0.02(0.06)$ & $0.01(0.07)$ & 0.418 \\
\hline
\end{tabular}

\section{4. 논의 및 제언}

본 연구는 합창활동에 참여하는 여성 노인의 음성 특성 및 음 성관련 삶의 질을 알아보고, 이를 합창활동 참여 유형에 따라 비교하여 분석하고자 하였다. 본 연구에서는 노인 합창단에서 활동하고 있는 여성 합창단원을 대상으로 합창 경험과 관련한 설문조사와 주관적 건강상태, 주관적 음성인식, K-VRQOL, GRBAS를 비교 분석하는데 목적을 두었다. 77 명 노인의 개인적 특성을 빈도분석을 실시하여 알아보았고, 합창관련 변인 및 응 답자의 주관적 평가 변인(주관적 건강상태, 주관적 음성인식, $\mathrm{K}-\mathrm{VRQOL})$, 언어치료사가 평가한 GRBAS를 통해 합창활동 참 여 유형에 따라 합창단과 찬양단으로 분류하여 $t$ 검정을 실시하 고 집단 간의 차이를 알아보았다. 이상의 결과를 바탕으로 합창 활동에 참여하는 여성노인의 음성 특성 및 음성관련 삶의 질을 비교한 논의점은 다음과 같다.

첫째, 합창활동 관련 변인에 해당하는 합창단 참여기간, 무대 공연 참여 횟수, 주당 연습시간 및 합창단 참여 만족도에서 합 창단과 찬양단간의 그룹별 차이를 발견할 수 있었다. 합창단원 
의 경우 찬양단원에 비해 참여기간이 짧고, 무대 공연 참여 횟 수가 적으며 평균 연습시간이 길게 나타났지만 합창 활동 만족 도 및 합창단 내 사회활동 만족도를 높게 평가하였다. 입단 신 청 및 입단 테스트를 거쳐 공식적인 단체로 활동하는 합창단의 경우 공연과 경연이라는 그룹 공동의 지향성을 가지고 1 년 단 위로 활동에 참여하게 된다. 그렇기 때문에 합창단 참여 기간이 짧지만 찬양단에서 활동하는 응답자들에 비해 주간 연습시간 이 길어 음악적 완성도를 높일 수 있었으며, 이로 인해 개인이 지각하는 합창활동에 대한 만족도를 높게 평가하는 결과를 가 져왔다. 이와 같은 결과는 노년기 여가활동으로써 합창활동이 성공적 노후생활에 긍정적인 영향을 미칠 수 있다는 선행연구 결과를 뒷받침한다(Na, 2004; Yoon, 2015). 또한 무대 경험은 특 정 파트의 구성원으로 맡은 역할을 성공적으로 해냈을 때, 긍정 적인 무대 경험을 통한 성취감뿐 아니라 노래 부르기 활동에 대 한 적극적인 태도를 형성해주며 궁극적으로는 자신의 목소리에 대한 자신감을 갖는데 도움을 준다(Bartolome, 2012; Chong et al., 2014; Kim, 2014; Kim, 2019; Lamont et al., 2017). 따라서 노년기 여가활동으로써 합창단 참여는 참여기간 및 빈도 등의 요인보 다 공연, 경연 등의 활동 지향성을 가지고 참여했을 때 합창단 원의 활동 참여 구속력을 강화할 수 있으며, 이에 따라 합창단 원의 활동 참여 만족도를 높일 수 있음을 시사한다.

둘째, 언어치료사의 GRBAS 평정과 참여자의 주관적 음성인 식, K-VRQOL에서 두 집단 간의 차이를 발견할 수 있었다. 먼저 GRBAS 점수는 각 항목의 집단 간 차이가 통계적으로 유의미하 지 않았으며 평균값의 차이가 크지 않았다. 다음으로, 주관적 음성인식 점수 중 대화 시 음성 만족도 항목에서 통계적으로 유 의미한 집단 간 차이가 나타났다. 합창단원의 경우 찬양단에 비 해 평균값이 높으며, 대화 시 음성 만족도를 긍정적으로 평가한 다는 점을 발견할 수 있었다. 마지막으로 K-VRQOL 척도 내 신 체 기능영역에 해당하는 전문적인 활동에서의 음성사용 및 타 인과의 소통에서 음성사용을 평가하는 두 문항에서 통계적으 로 유의미한 집단 간 차이가 나타났다. 합창단원의 경우 찬양단 원에 비해 위 두 문항을 긍정적으로 평가한다는 점을 발견할 수 있었다. 응답자가 주관적으로 평가한 주관적 음성인식 수준과 $\mathrm{K}-\mathrm{VRQOL}$ 에서는 합창단원의 경우 대화상황에서 본인의 음성 에 대한 만족도를 높게 평가하며, 음성관련 전문 활동이나 의사 소통 상황에서 본인 음성과 삶의 질을 보다 긍정적으로 지각하 는 것으로 나타났다. 이와 같은 결과는 합창단과 찬양단의 두 집단에서 나타나는 입단 과정, 구속력의 강도, 그룹의 지향성 및 공연에서의 음악적 완성도 등에서 보여지는 두 집단의 차별 적인 특성과 연결될 수 있다. 무대공연 시 음악적 완성도에 중 점을 두고 활동하는 합창단에서 이루어지는 노래 교육 프로그 램은 음성의 기능적 사용에 대한 개인의 주관적 인식 수준을 향 상시키는데 긍정적인 영향을 미칠 수 있음을 시사한다. 이는 체 계적인 노래 교육 프로그램이 음성 개선뿐만 아니라 참여자의 VHI, V-RQOL 등에서 주관적인 음성만족도의 향상을 확인했다 는 선행연구 결과를 뒷받침한다(Cassol et al., 2014; Chung, 2016; Han, 2015).
합창활동에 참여하고 있는 여성 노인의 그룹별 합창단 특성 및 개별 합창 경력을 살펴본 결과, 합창단원이 찬양단원에 비해 합창활동 참여 만족도가 높은 것을 확인할 수 있었다. 체계적이 며 공식적으로 운영되는 단체 활동으로써 합창단에 소속되어 성공적으로 경연 또는 공연에 참가하는 것을 목적으로 합창 활 동에 참여할 때 활동 참여 만족도가 높은 것을 확인할 수 있었 다. 이는 노년기 여가활동으로써 성취감 또는 긍정적인 성공경 험을 통해 활동 참여 만족도를 높일 수 있는 체계적인 노래 부 르기 그룹 음악 프로그램의 필요성을 시사하고 있다. 본 연구의 결과를 바탕으로 향후 노인을 대상으로 합창 그룹을 구성하고 활동을 진행할 때 노년기 삶의 질을 높일 수 있는 보다 구체적 인 활동 방향성을 제시할 수 있을 것이다.

또한, 합창활동에 참여하고 있는 본 연구의 모든 대상자의 경 우 전문가의 음성평가에서 정상범주의 음성기능 사용을 보이 는 것으로 나타났으나, 찬양단원에 비해 합창단원의 경우가 기 능적인 측면에서 음성사용에 대해 긍정적으로 지각하는 것으 로 나타났다. 따라서 활동 지향적이며 보다 체계적인 합창활동 참여는 음성 사용에 대한 주관적 인식 수준에 긍정적인 영향을 미친다는 것을 확인할 수 있다. 더불어 노년기에 음성의 변화를 이끌어내기 위해서는 기존의 합창 프로그램보다 건강한 음성 사용 및 음성 기능 개선을 위한 전문적인 중재 프로그램의 연구 가 필요함을 시사하고 있다.

본 연구의 제한점으로는 합창 활동을 전혀 하지 않는 노인 집 단을 대조군으로 제시하지 못하였다는 점이다. 후속 연구에서 는 대조군과의 비교를 통해 노년기의 합창 활동의 필요성을 강 조할 수 있을 것이다. 또한 본 연구는 연구 대상자 모집 시 서울 과 부산으로 지역이 한정되었으며, 여성 노인을 대상으로 하여 성별의 제한이 있었다. 이러한 표본 크기의 제한으로 본 연구의 결과를 일반화하는데 어려움이 있다고 평가되므로 추후 연구 에서는 대상자의 수 및 지역, 성별을 확대하여 성별 차이 및 지역 적, 문화적 차이를 고려한 연구가 필요하리라 판단된다. 마지막 으로 본 연구에서는 합창의 유형에 따른 기존 연구가 전무하여 이에 따른 정확한 지표 선정 및 요인 분석에 제한이 있었다. 추후 이를 보완, 확장한 연구가 추가적으로 필요하리라사료된다.

\section{References}

Bailey, B. A., \& Davidson, J. W. (2003). Amateur group singing as a therapeutic instrument. Nordic Journal of Music Therapy, 12(1), 18-32.

Bartolome, S. J. (2012). It's like a whole bunch of me!: The perceived values and benefits of the Seattle girls' choir experience. Journal of Research in Music Education, 60(4), 395-418.

Boone, D. R., McFarlance, S. C., Von Berg, S. L., \& Zraick, R. I. (2010). The voice and voice therapy (8th ed). Boston, MA: Allyn $\&$ Bacon.

Cassol, M., \& Bós, Â. J. G. (2014). Vocal and depressive benefits of choral singing. PAJAR - Pan American Journal of Aging Research, 
2(2), 40-43

Chang, P. J., Wray, L., \& Lin, Y. (2014). Social relationships, leisure activity, and health in older adults. Health Psychology, 33(6), 516-523.

Choi, J. S. (2019). A study on characteristics of the vocal cords for aging choir members (Master's thesis). Gwangju University, Gwangju, Korea.

Chong, H. J., Kim, J. H., \& Kim, S. J. (2014). The concept of arts-character education in arts education. The Journal of Educational Studies, 45(1), 53-72.

Chung, Y. M. (2016). Effects of choral singing on improvement of vocal function and satisfaction among patients with Parkinson's disease (Master's thesis). Ewha Womans University, Seoul, Korea.

D'haeseleer, E., Claeys, S., Bettens, K., Leemans, L., Van Calster, AS., Van Damme, N., Thijs, Z., ․ Van Lierde, K. (2017). The impact of a teaching or singing career on the female vocal quality at the mean age of 67 years: A pilot study. Journal of Voice, 31(4), 516.e19-516.e26.

Elefant, C., Baker, F. A., Lotan, M., Lagessen, S. K., \& Skeie, G. O. (2012). The effect of group music therapy on mood, speech, and singing in individuals with Parkinson's disease-a feasibility study. Journal of Music Therapy, 49(3), 278-302.

Etter, N. M., Hapner, E. R., Barkmeier-Kraemer, J. M., GartnerSchmidt, J. L., Dressler, E. V., \& Stemple, J. C. (2019). Aging voice index (AVI): Reliability and validity of a voice quality of life scale for older adults. Journal of Voice, 33(5), 807e7-807e12.

Gregory, N. D., Chandran, S., Lurie, D., \& Sataloff, R. T. (2012). Voice disorders in the elderly. Journal of Voice, 26(2), 254-258.

Gu, M. K., \& Sok, S. R. (2018). Influence of leisure activity participation between genders among Korean older adults, Journal of Gerontological Nursing, 44(11), 51-58.

Hamdan, A. L., Sataloff, R. T., \& Hawksaw, M. J. (2019). Impact of aging on the voice. Laryngeal Manifestations of Systemic Diseases (pp. 49-52). San Diego, CA: Plural.

Han, E. Y. (2015). Use of the structured singing activities to improve of the vocal quality and alleviate of the depression symptoms for clients with Parkinson's disease: Case studies (Master's thesis). Ewha Womans University, Seoul, Korea.

Han, S. J. (2017). The relationship between self-perceived benefits from singing and quality of life in older adults aged over 75 years. Journal of Music and Human Behavior, 14(1), 63-84.

Hirano, M. (1981). Clinical examination of voice (pp. 81-84). New York, NY: Springer Verlag.

Hong, H. J., \& Kim, S. J. (2016). Vocal range of older adults in comparison with young adults depending on the presence of pitch cues. Journal of the Korea Contents Association, 16(4), 377-386.

Johnson, J. K., Stewart, A. L., Acree, M., Nápoles, A. M., Flatt, J. D., Max, W. B., \& Gregorich, S. E. (2018). A community choir intervention to promote well-being among diverse older adults: Result from the community of voice trial. The Journals of Gerontology: Series B, 75(3), 549-559.

Jun, H. U., \& Kim, S. J. (2011). Effects of respiration and oral motor training based on musical elements and singing on voice of healthy elderly. Journal of the Korea Contents Association, 11(10), 380-387.

Kang, H. N., Kim, S. H., Yoo, J. Y. Kan, H., Ki, S., \& Yoo, J. (2018). Voice hygiene habits and the characteristics of Korean VoiceRelated Quality of Life (K-VRQOL) among classical singers. Phonetics and Speech Sciences, 10(3), 49-59.

Kendall, K. (2007). Presbyphonia: A review. Current Opinion in Otolaryngology \& Head and Neck Surgery, 15(1), 137-140.

Kim, E. H. (2019). Mixed study on the effects of intramural chorus competition on music attitude and flow experience of students in high school (Master's thesis). Ewha Womans University, Seoul, Korea.

Kim, J. H. (2019). Therapeutic rationale for music therapy interventions with older adults: An analysis of the literature. Journal of Music and Human Behavior, 16(2), 53-77.

Kim, J. O., Lim, S. E., Park, S. Y., Choi, S. H., Choi, J. N., \& Choi, H. S. (2007). Validity and reliability of Korean version of handicap index and voice-related quality of life. Speech Science, 14(3), 111-125.

Kim, S. J. (2014). A study on the effects of choral education on youth's emotion and character building (Master's thesis). Mokpo National University, Mokpo, Korea.

Kim, S. T. (2010). The effects of voice therapy in age-related dysphonia. Phonetics and Speech Sciences, 2(2), 117-121.

Kim, S. Y. (2019). The pitch characteristics of patients with Parkinson's disease during singing: Centered on Arirang (Master's thesis). Ewha Womans University, Seoul, Korea.

Kim, Y. J. (2018). Singing to alleviate of the depression symptoms in the oldest-old women living at home: Case studies (Master's thesis). Ewha Womans University, Seoul, Korea.

Korea Institute for Health and Social Affairs (2014). Survey on the actual condition of the elderly 2014. Sejong, Korea: Korea Institute for Health and Social Affairs.

Lamont, A. (2012). Emotion, engagement and meaning in strong experiences of music performance. Psychology of Music, 40(5), 574-594.

Lamont, A., Murray, M., Hale, R., \& Wright-Bevans, K. (2017). Singing in later life: The anatomy of a community choir. Psychology of Music, 46(3), 424-439.

Lee, E. A. (2014). The study on the actual utilization of music for the depression of the elderly people (Master's thesis). Ewha Womans University, Seoul, Korea.

Lee, H. J. (2006). Age and sex difference in acoustic parameters of 
middle age and elderly adult voice (Master's thesis). Korea Nazarene University, Cheonan, Korea.

Lee, S. J., Cho, Y. H., Song, J. Y., Lee, D. H., Kim, Y. J., \& Kim, H. H. (2015). Aging effect on Korean female voice: Acoustic and perceptual examinations of breathiness. Folia Phoniatrica et Logopaedica, 67(6), 300-307.

Lee, S. Y. (2010). A comparative study on the perception of the successful aging between women and men. Gender and Culture, 3(1), 99-130.

Lortie, C. L., Rivard, J., Thibeault, M., \& Tremblay, P. (2017). The moderating effect of frequent singing on voice aging. Journal of Voice, 31(1), 112.e1-12.

Moon, S. Y., Park, J. W., \& Yang, S. A. (2019). The effects of AOS (Alexander technique - oral motor and respiratory exercise - song psychotherapy) music intervention on the vocal hygiene and psychological wellbeing of the elderly. Korean Journal of Gerontological Social Welfare, 74(3), 65-91.

$\mathrm{Na}, \mathrm{H}$. J. (2004). A study on the role of leisure of the elderly for upgrading of the quality of life. Journal of the Korea Gerontological Society, 24(1), 53-70.

Park, S. Y., \& Youn, G. H. (2019). A brief review of reminiscence Music Therapy for improving quality of life in old age. Korean Journal of Research in Gerontology, 28(2), 95-108.

Prakup, B. (2012). Acoustic measures of the voices of older singers and nonsingers. Journal of Voice, 26(3), 341-350.

Rosa, M., \& Behlau, M. (2017). Mapping of vocal risk in amateur choir. Journal of Voice, 31(1), 118.e1-11.

Ruud, E. (1997). Music and the quality of life. Nordic Journal of Music Therapy, 6(2), 86-97.

Sobolewska, A., Claros, P., Pujol, C., Claros-Pujol, A., \& Claros, A. (2019). Aspects of ageing on professional opera singer's voice preliminary findings. Otolaryngologia Polska, 73(4), 29-34.

Song, Y. K. (2012). Prevalence of voice disorders and characteristics of Korean voice handicap index in the elderly. Phonetics and Speech Sciences, 4(3), 151-159.

Song, Y. K., Jin, S. M., Sim, H. S., Kwon, K. H., Lee, K. C., \& Lee, Y. B. (2000). The effect of voice disorders on quality of life (QOL) in the Korean. The Journal of the Korean Society of Logopedics and Phoniatrics, 11(1), 51-63.

Tay, E. Y. L., Phyland, D. J., \& Oates, J. (2012). The effect of vocal function exercises on the voices of aging community choral singers. Journal of Voice, 26(5), 672.e.19-672.e27.

Unwin, M. M., Kenny, D. T., \& Davis, P. J. (2002). The effect of group singing on mood. Psychology of Music, 30(2), 175-185.

Verdonck-de Leeuw, I. M., \& Mahiue, H. F. (2004). Vocal aging and the impact on daily life: A longitudinal study. Journal of Voice, 18(2), 193-202.

Yang, H. J. (2019). The benefits of choir singing recognized by the middle-aged and older male choir (Master's thesis). Ewha Womans University, Seoul, Korea.

Yim, A. R., Kim, H. H., Kim, S. R., \& Yoo, H. J. (2013). Review on age-related voice changes and quality of life. Journal of Rehabilitation Research, 17(1), 259-276.

Yoon, H. J. (2015). A systematic review of the research on older adults leisure and suggestions for future research. Journal of Tourism \& Leisure Research, 27(7), 169-186.

\section{- 이현정 (Hyeonjung Lee)}

이화여자대학교 일반대학원 음악치료학과 석사 서울시 서대문구 이화여대길 52

Email: hjung_089@naver.com 관심분야: 음악치료, 음성학, 노년학

(사) 전국음악치료사협회 음악중재전문가(KCMT)

\section{- 강빈나 (Binna Kang)}

이화여자대학교 일반대학원 음악치료학과 연구생

서울시 서대문구 이화여대길 52

Email: shinybinna@hanmail.net

관심분야: 음악치료, 음성학, 노년학

(사) 전국음악치료사협회 음악중재전문가(KCMT)

- 김수지 (Soo Ji Kim) 교신저자

이화여자대학교 교육대학원 음악치료교육전공 주임교수 서울시 서대문구 이화여대길 52 대학원관 209호

Tel: 02-3277-6917

Email: specare@ewha.ac.kr

관심분야: 음악치료, 음성학, 노년학

미국 University of Kansas 음악치료학 박사

미국 공인 음악치료사(MT-BC)

(사) 전국음악치료사협회 음악중재전문가(KCMT) 


\section{부록}

설문지 1.

인구사회학적 정보(1 3), 합창단 참여 경험(4 10), 주관적 건강

상태 인식(11), 주관적 음성인식 만족도(12 16)

\begin{tabular}{l}
\hline 1. 이름: \\
\hline 2. 출생년도: \\
\hline 3. 지역 : \\
\hline 4 10지금부터는 현재 활동하고 있는 합창단에 관한 항목입니다. \\
4. 현재 활동하고 있는 합창단의 구성을 표시해 주세요. \\
(1) 여성합창 (2) 남.여 혼성합창
\end{tabular}

5. 현재 활동하고 있는 합창단에서 맡고 있는 파트를 표시해 주세 요.

(1) 소프라노 (2) 메조 소프라노 (3) 알토

6. 현재 활동하고 있는 합창단에 참여한 기간을 적어주세요. 이 합창단에서_년원부터 활동

7. 현재 활동하고 있는 합창단은 얼마나 자주 연습하는지 표시해 주세요.

일주일에 회, 한 번에 시간 __ 분

8. 현재의 합창단을 활동하면서 본인이 참여했던 공연 및 합창대회 의 총 참여 횟수를 적어주세요.

1년 동안 회

9 10. 아래 문항을 잘 읽고 적절한 수준을 선 위에 세로선(|)으로 그어주세요.

9. 나는 합창단에서 노래 부르는 것이 좋다.

$\begin{array}{cc}\text { 매우 } & \text { 매우 } \\ \text { 그렇지 않다 } & \text { 그렇다 }\end{array}$
10. 나는 합창단에 참여하면서 사람들을 만나며 사회적 활동을 하 는 것이 좋다.

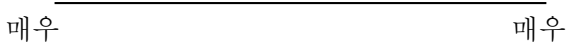
그렇지 않다그렇다

11. 현재 건강상태는 어떻다고 생각하십니까?

(1) 매우 나쁘다 (2) 나쁘다 (3) 보통이다 (4) 좋다 (5) 매우 좋다

12 16. 지금부터는 현재 나의 목소리에 관한 인식에 관한 항목입니 다.

$1=$ 전혀 그렇지 않다

2 =그렇지 않다

$3=$ 그렇다

$4=$ 매우 그렇다

\begin{tabular}{ll}
\hline 12. 나는 내 음성에 만족하다. & 12345 \\
\hline 13. 나는 내 음성에 이상이 있다고 생각한다 & 12345 \\
\hline 14. 나는 말할 때 내 음성이 괜찮다고 생각한다. & 12345 \\
\hline 15. 나는 노래할 때 내 음성이 괜찮다고 생각한다. & 12345 \\
\hline 16. 나는 합창을 하면서 내 음성이 좋아졌다고 생각한다. & 12345 \\
\hline
\end{tabular}




\title{
여성 노인 합창단원의 합창단 유형에 따른 청지각적 음성평가(GRBAS) 및 음성관련 삶의 질 $(\mathrm{K}-\mathrm{VRQOL})$ 비교*
}

\author{
이 현 정 ${ }^{1}$ 강 빈 나 ${ }^{1}$ 김 수 지 ${ }^{2}$ \\ ${ }^{1}$ 이화여자대학교 일반대학원 음악치료학과 \\ 2이화여자대학교 교육대학원 음악치료교육전공
}

\begin{abstract}
국문초록
본 연구의 목적은 음성의 청지각적 평가도구(GRBAS)와 음성관련 삶의 질(K-VRQOL) 척도를 통해 합창활동에 참 여하는 여성 노인의 음성 특성과 음성관련 삶의 질을 비교하는 것이다. 연구 대상은 서울 및 부산 소재의 합창단에 서 활동 중인 만 60 세 이상의 여성 노인으로 총 77명이었다. 합창단은 참여 유형에 따라 합창단(Regular choir)과 찬 양단(Church choir) 두 개의 집단으로 분류하였다. 청지각적 음성평가는 /a/ 모음을 발성하는 음성을 듣고 전문가가 청지각적 평가(GRBAS) 척도를 사용하여 평정하였다. 연구 결과, 합창활동 참여 유형에 따라 집단 간 차이를 비교 했을 때 찬양단에서 활동하는 여성 노인에 비해 합창단에서 활동하는 여성 노인의 경우 주관적 음성 인식 수준에 서 대화 시 음성 사용 만족도가 높은 것으로 나타났다. 또한, 음성관련 삶의 질(K-VRQOL) 척도의 신체 기능 영역에 해당하는 문항에서 만족도가 높은 것으로 분석되었다. 본 연구는 합창활동이 노년기 음성기능의 개선뿐 아니라 음 성사용의 주관적 인식 수준을 향상시키는데 긍정적인 결과를 기대할 수 있을 것이라는 점을 확인하였으며, 노인 음성개선을 위한 체계적인 음악 중재 프로그램의 필요성을 시사하고 있다.
\end{abstract}

핵심어: 노인 합창, 여성 노인 합창, 합창활동, 음성관련 삶의 질 척도 $(\mathrm{K}-\mathrm{VRQOL})$, 청지각적 음성 평가 척도 (GRBAS)

\section{참고문헌}

강하늘, 김선희, 유재연 (2018). 성악가의 음성위생 습관과 한국 어판 음성관련 삶의 질(K-VRQOL) 특성. 말소리와 음성과학, 10(3), 49-59.

김선주 (2014). 합창음악교육이 청소년의 정서발달과 인격형성 에 미치는 영향. 목포대학교 석사학위논문.

김성태 (2010). 노인성 음성장애의 음성치료 효과. 말소리와 음성 과학, 2(2), 117-121.

김소연 (2019). 파킨슨병 환자의 가창 시 음고 특성: 아리랑 노래 를 중심으로. 이화여자대학교 석사학위논문.

김유정 (2018). 초고렁 재가여성노인의 우울감 완화를 위한노래 부르기 사례. 이화여자대학교 석사학위논문.

김은혜 (2019). 교내 합창대회가 고등학생의 음악적 태도와 몰입 경험에 미치는 영향에 대한 혼합연구. 이화여자대학교 석사 학위논문.

김재옥, 임성은, 박선영, 최성희, 최재남, 최홍식 (2007). 한국어판 음성장애지수 및 음성 관련 삶의 질의 타당도 및 신뢰도 연구.
음성과학, 14(3), 111-125.

김지현 (2019). 국내 노인 대상 음악중재연구 내 치료 논거 세부 분석. 인간행동과 음악연구, 16(2), 53-77.

나항진 (2004). 삶의 질 향상을 위한 노인 여가의 역할에 관한 연 구. 한국노년학, 24(1), 53-70.

문소영, 박지원, 양수아 (2019). AOS 음악중재가 노년기 음성건 강과 심리적 복지감에 미치는 영향. 노인복지연구, 74(3), 65-91.

박소영, 윤가현(2019). 노년기 삶의 질 향상을 위한 음악치료 회 상기법에 관한 소고. 한국노년학연구, 28(2), 95-108.

송윤경 (2012). 노인 음성장애 출현율 및 음성장애지수 특성. 말 소리와 음성과학, 4(3), 151-159.

송윤경, 진성민, 심현섭, 권기환, 이경철, 이용배 (2000). 한국인의 음성질환이 삶의 질에 미치는 영향. 대한음성언어의학회지, 11(1), 51-63.

양혜정 (2019). 중노년 남성 합창단원이 인식하는 합창의 심리. 사회적 혜택. 이화여자대학교 석사학위논문.

윤현숙, 유희정 (2006). 가족관계가 성공적 노화에 미치는 영향.

* 이 연구는 제 1 저자의 2020 년도 석사학위 논문을 수정, 보완한 것입니다. 
한국가족복지학, 18(1), 5-31.

윤혜진 (2015). 노인여가 연구의 학문적 동향 및 연구 제언. 관광 레저연구, 27(7), 169-186.

이신영 (2010). 성공적 노화 인식에 관한 성별 비교 연구. 젠더와 문화, 3(1), 99-130.

이은애 (2014). 노인의 우울 수준에 따른 음악 활용 실태 연구. 이 화여자대학교 석사학위논문.

이효진 (2006). 장노년기 성인 음성의 성과 연령에 따른 음향음 성학적 특성 비교. 나사렛대학교 석사학위논문.

임애리, 김향희, 김수현, 유현지 (2013). 문헌분석을 통한 노화에 따른 음성의 특징과 삶의 질 변화. 재활복지, 17(1), 259-276.

전희운, 김수지 (2011). 음악요소와 노래 부르기를 활용한 호흡 및 구강훈련이 정상노인의 음성에 미치는 영향. 한국콘텐츠 학회논문지, 11(10), 380-387.

정유미(2017). 합창 중재 프로그램이 파킨슨병 환자의 음성개선 및 음성 만족도에 미치는 영향. 이화여자대학교 석사학위논문. 정현주, 김정희, 김수지 (2014). 예술교육에서 예술인성교육의 개 념. 교육과학연구, 45(1), 53-72.

최진석 (2019). 합창단원의 고령화에 따른 성대 특성에 관한 연 구. 광주대학교 석사학위논문.

한국보건사회연구원 (2014). 2014년도 노인실태조사. 세종: 한국 보건사회연구원.

한수진 (2017). 75세 이상 노인이 지각하는 노래부르기의 혜택과 삶의 질. 인간행동과 음악 연구, 14(1), 63-84.

한은영(2015). 구조화된 노래활동을 통한 파킨슨병 내담자의 음 성의 질 향상과 우울 감소에 관한 사례. 이화여자대학교 석사 학위논문.

홍혜진, 김수지 (2016). 음정제시 유무에 따른 노인과 성인의 음 역대 비교. 한국콘텐츠학회논문지, 16(4), 377-386. 